\title{
Geothermobarometry of the Dudatoli-Almora Crystallines, Garhwal, Kumaun Lesser Himalaya
}

\author{
Tejender N J owhar \\ Wadia Insitute of Himalayan Geology, 33 GMS Road, Dehra Dun 248 001, INDIA \\ For correspondence, E-mail: tnjowhar@rediffmail.com
}

The Garhwal and Kumaun regions of the Himalaya in Uttaranchal State of India are critical areas for studying the typical characteristics of the Himalayan fold-and-thrust belt, in contrast to the areas in close proximity of the northeast and northwest Himalayan syntaxes, where complications arise due to strike-slip faulting. In this region, the Lesser Himalaya is characterized by the occurrence of many crystalline bodies of varying dimensions, of which synformally disposed DudatoliAlmora Crystalline Zone (ACZ) is the largest. Dudatoli-Almora Crystallines (also called Almora Klippen) constitutes one of the most important tectonic units in the Garhwal-Kumaun Lesser Himalaya and it is the remnant of a large thrust sheet nappe that moved southward from the Higher Himalayan Crystalline Zone, to rest over the Lesser Himalayan Volcano-Sedimentary belt. The Almora klippen consists of amphibolite grade metapelites, quartzites, augen gneisses and granites belonging to the Precambrian Almora Group. At places, the greenschist grade metapelites of the Precambrian Ramgarh Group (Chails) occur underneath the Almora Group, forming a series of lower klippen.

The North Almora Thrust (NAT) marks the northern boundary of the Almora klippen, its southern margin is bound by the South Almora Thrust (SAT). The metamorphic sequence of the Almora Klippen exhibits regional metamorphism of Barrovian type, which increases progressively upward in the sequence from peripheral part to the central part of the synform. In Champawat and Almora areas the metamorphism is largely restricted to the chlorite, biotite and garnet zones; however, in the Dudatoli-Bungidhar regions, the metamorphic grade reaches upto staurolite-kyanite and biotite-sillimanite zones.

The EPMA data on garnet, biotite, muscovite and plagioclase were obtained on twenty samples collected from Chamoli, Pauri and Almora districts of Garhwal and Kumaun Himalaya by utilizing JEOL-8600 M super microprobe. In the rim of garnet, $\left(\mathrm{X}_{\mathrm{Mg}} / \mathrm{X}_{\mathrm{Fe}}\right)$ varies from 0.053 to $0.297, \mathrm{X}_{\mathrm{Almandine}}$ varies from 0.488 to 0.780 and $(\mathrm{Ca}+\mathrm{Mn}) /(\mathrm{Ca}+\mathrm{Mn}+\mathrm{Fe}+\mathrm{Mg})$ varies from
0.065 to 0.423 . In the core of garnet, $\left(\mathrm{X}_{\mathrm{Mg}} / \mathrm{X}_{\mathrm{Fe}}\right)$ varies from 0.030 to $0.279, \mathrm{X}_{\text {Almandine }}$ varies from 0.487 to 0.753 and $(\mathrm{Ca}+\mathrm{Mn}) /$ $(\mathrm{Ca}+\mathrm{Mn}+\mathrm{Fe}+\mathrm{Mg})$ varies from 0.118 to 0.461 . Ti in garnets is significantly low, in the rim it varies from 0.004 to 0.012 and in cores 0.008 to 0.115 . In the rim of biotites, $\left(\mathrm{X}_{\mathrm{Mg}} / \mathrm{X}_{\mathrm{Fe}}\right)$ varies from 0.513 to 2.245 , $\left(\mathrm{Al}^{\mathrm{VI}}+\mathrm{Ti}\right) /\left(\mathrm{Al}^{\mathrm{VI}}+\mathrm{Ti}+\mathrm{Fe}+\mathrm{Mg}\right)$ varies from 0.142 to 0.204 and $\mathrm{X}_{\text {Phlogopite }}$ from 0.270 to 0.579 . In the core of biotites, $\left(\mathrm{X}_{\mathrm{Mg}} / \mathrm{X}_{\mathrm{Fe}}\right)$ varies from 0.547 to $2.198,\left(\mathrm{Al}^{\mathrm{VI}}+\mathrm{Ti}\right) /\left(\mathrm{All}{ }^{\mathrm{V}}+\mathrm{Ti}+\mathrm{Fe}+\mathrm{Mg}\right)$ varies from 0.125 to 0.216 and $\mathrm{X}_{\text {phlogopite }}$ from 0.277 to 0.581 . In all the samples from Dudatoli-Almora crystallines $(\mathrm{Ca}+\mathrm{Mn}) /$ $(\mathrm{Ca}+\mathrm{Mn}+\mathrm{Fe}+\mathrm{Mg})$ in garnets exceeds value of 0.2 or $\left(\mathrm{Al}^{\mathrm{V}}+\mathrm{Ti}\right) /$ $\left(\mathrm{Al}^{\mathrm{V}}+\mathrm{Ti}+\mathrm{Fe}+\mathrm{Mg}\right)$ in biotite exceeds value of 0.15 . P-T estimates have been done on the Dudatoli-Almora Crystallines in order to place quantitative constraints on the conditions attained during the regional metamorphism. P-T calculations were carried out using computer programs BGT (Jowhar 1999), GPT (Reche and Martinez 1996), TWQ (Berman 1991), WEBINVEQ (Gordon 1998). GPT computer program (Reche and Martinez, 1996) was used for simultaneous solution of $\mathrm{P}$ and $\mathrm{T}$. For $\mathrm{P}$ estimation garnetplagioclase-muscovite-biotite-quartz geobarometer and for T estimation various models of garnet-biotite geothermometer were utilized. It is interpreted that in Dudatoli-Almora Crystallines T varies from 500 to $650{ }^{\circ} \mathrm{C}$ and $\mathrm{P}$ from 6 to $8 \mathrm{kbar}$. Spatial distribution of data indicates inverted metamorphism.

\section{References}

Berman RG. 1991. Thermobarometry using multiequilibrium calculations: a new technique with petrologic applications. Canadian Mineralogist 29: $833-855$

Gordon TM. 1998. WEBINVEQ Thermobarometry: An experiment in providing interactive scientific software on the World Wide web. Computers \& Geosciences 24(1): 43-49

JowharTN. 1999. BGT: A FORTRAN 77 computer program for biotite-garnet geothermometry. Computers \& Geosciences 25: 609-620

Reche J and FJ Martinez. 1996. GPT: An EXCEL spreadsheet for thermobarometric calculations in metapelitic rocks. Computers and Geosciences 25: 775-784 